\title{
Hasil Belajar Siswa Ditinjau Dari Gaya Belajar
}

\author{
Isnanto \\ FIP Universitas Negeri Gorontalo \\ Mandarwati A. Hamu \\ FIP Universitas Negeri Gorontalo \\ email: isnanto@ung.ac.id
}

Received: 13 August 2021; Revised: 02 October 2021; Accepted: 28 December 2021

DOI: http://dx.doi.org/10.37905/aksara.8.1.547-562.2022

\begin{abstract}
Abstrak
Tujuan penelitian, untuk mengetahui gaya belajar siswa dan untuk mengetahui ada tidaknya perbedaan hasil belajar ditinjau dari gaya belajar siswa kelas VI SDN No. 42 Hulonthalangi Kota Gorontalo. Penelitian ini menggunakan pendekatan kuantitatif bersifat deskriptif dengan metode ex post facto. Teknik pengumpulan data melalui kuesioner dan dokumentasi, sampel yaitu 22 siswa. Teknik analisis data dengan analisis deskriptif. Hasil penelitian dari 22 siswa terdapat 11 siswa dengan kecenderungan gaya belajar visual yang mempunyai hasil belajar pada mata pelajaran IPA dengan rata- rata nialai yaitu 72,4, 7 siswa dengan kecenderungan gaya belajar auditori dengan hasil belajar pada mata pelajaran IPA yaitu rata-rata 67 dan 4 siswa dengan kecenderungan gaya belajar kinesetik yang mempunyai hasil belajar pada mata pelajaran IPA yaitu rata-rata 64,5 .
\end{abstract}

\section{Kata Kunci}

Gaya Belajar; Hasil Belajar.

\section{PENDAHULUAN}

Belajar dikatakan berhasil jika mendapatkan hasil belajar yang baik. Hasil belajar didapat dari apa yang kita dapatkan dari proses belajar tersebut. Perolehan nilai dari hasil belajar merupakan salah satu indikator dari keberhasilan belajar itu sendiri. Tiap individu berbeda tingkatan dalam memperoleh hasil belajar atau hasil dari proses belajar tersebut. Dalam belajar tentunya terdapat banyak macam karakteristik dan perilaku siswa beserta kemampuan seseorang dalam menyerap pembelajarandan faktor-faktor yang mempengaruhi hasil belajar antara lain: faktor internal dan eksternal. Pada faktor eksternal antara lain keluarga, sekolah, dan masyarakat adapau faktor internal yaitu salah satunya yaitu faktor gaya belajar siswa.

Memahami dan menyerap pelajaran adalah kemampuan seseorang yang pasti berbeda tingkat kemampuannya. Ada yang sangat lambat, ada yang sedang dan ada pula yang yang sangat cepat dalam memahami sebuah informasi atau pelajaran karenanya mereka seringkali harus menempuh cara berbeda. Cara dalam memahami ataupun menyerap infomasi atau pelajaran adalah gaya belajar seseorang. Gaya belajar merupakan cara menyerap dan mengolah informasi atau pelajaran dalam diri individu. Gaya belajar 
siswa sendirilah yang mampu menyerap dan mengolah informasi atau pengetahuan itu dengan lebih mudah. Oleh karena itu, memperkenalkan ataupun mengarahkan siswa dalam mengenali gaya belajar sesuai dengan dirinya sendiri akan membantu dalam menyerap informasi secara baik, optimal, dan efektif sehingga akan membantu peningkatan prestasi. Menurut DePorter dan Hernacki (2005) mengemukakan bahwa terdapat tiga macam dalam gaya belajar yaitu visual, auditorial, dan kinestetik. Gaya belajar yang sesuai dengan diri manusia itu sendiri akan memudahkan proses belajar untuk mencapai hasil belajar yang maksimal dan memungkinkan dalam belajar lebih cepat tangkap apa yang dipelajarinya.

Penggunaan cara yang tepat sesuai dengan gaya belajarnya akan membantu siswa dalam menyerap informasi secara baik, optimal dan efektif sehingga akan membantu peningkatan prestasi belajar siswa. Penyataan tersebut sejalan dengan yang dikatakan Fitriani (2017) bahwa gaya belajar visual, auditori, dan kinestetik merupakan suatu kombinasi dari bagaiamana siswa menyerap, mengatur, dan mengolah informasi yang pada akhirnya akan mempengaruhi prestasi belajar. Gaya belajar tiap individu tidaklah sama tiap orang mempunyai gaya dalam menyerap dan mengolah infomasi atau pelajaran. Dengan begitu gaya belajar menjadi salah satu faktor penentu keberhasilan dalam belajar. Perbedaan seseorang sangatlah mempengaruhi cara dan hasil belajar mereka.

Sebagian siswa ada yang lebih menyukai guru mengajar dengan hanya menuliskan di papan tulis. Ada pula yang lebih tertarik pada guru yang cara mengajarnya hanya menyampaikan secara lisan dan mereka mendengarkan untuk bisa memahaminya. Ada juga yang lebih suka membentuk kelompok kecil untuk mendiskusikan pertanyaan yang menyangkut pelajaran tersebut atau dengan mepraktikkan langsung. Setiap orang mempunyai kemampuan yang berbeda tingkatnya dalam memperoleh atau menyerap informasi yang mereka dapatkan. Dengan begitu individu memiliki tingkatkan yang berbeda-beda dalam menyerap pelajaran yang merupakan bagian dari proses belajar dan akan mendaptkan hasil dari proses tersebut. Karena dalam belajar yang baik sudah pasti memperoleh hasil yang baik pula.

Berdasarkan hasil pengamatan pada bulan September 2019 di SDN No. 42 Hulonthalangi Gorontalo, yang peneliti lakukan yaitu mengamati siswa dengan melihat segala perbedaan karakteristik juga perbedaan tingkat kemampuan menyerap informasi atau pelajaran. Ada yang lebih suka pembelajaran yang memperlihatkan gambar-gambar dengan melihat langsung, ada yang senang ketika belajar dengan mendengarkan penjelasan- penjelasan guru dengan ceramah, juga ada siswa yang lebih senang belajar dengan langsung mempraktikkan dengan menggambar atau menuliskan dan banyak bergerak, tidak betah duduk berlama-lama. Adapun hasil belajar siswa pada mata pelajaran IPA yaitu beragam antara nilai 75-90.

Gaya belajar patutlah diperhatikan dalam proses pembelajaran agar mencapai hasil yang maksimal dan membuat siswa lebih nyaman dan mudah memperoleh informasi atau pelajaran. Mengetahui gaya belajar akan membantu siswa memahami pelajaran dengan lebih baik. Kurangnya pemahaman guru terhadap gaya belajar siswa berdampak merugikan siswa. Dari pembahasan diatas gaya belajar dapat mempengaruhi hasil belajar tiap siswa. Hal ini sejalan penelitian yang dilakukan Suyono (2018) dengan pendekatan 
kuantitatif menunjukan bahwa terdapat adanya pengaruh gaya belajar terhadap hasil belajar siswa yang dilakukan secara signifikan.Hasil belajar sangatlah penting untuk tercapainya suatu proses pembelajaran yang efektif dan dalam pencapaian tujuan belajar tersebut.

\section{METODE}

Penelitian ini dilakukan di kelas VI Sekolah Dasar Negeri No. 42 Hulonthalangi Kota Gorontalo. Metode dalam penelitian ini termasuk metode penelitian ex post facto.

Dalam penelitian ini yaitu: Gaya Belajar. Gaya belajar yang dimaksud ada tiga macam yaitu visual, auditori, dan kinestatik. Variabel dependen atau variabel terikat adalah variabel yang dipengaruhi atau yang menjadi akibat, karena adanya variabel bebas. Dalam penelitian ini yaitu hasil belajar. Hasil belajar yang dimaksud dalam penelitian ini hasil belajar PAS (Penilaian Akhir Semester) pada mata pelajaran IPA yang diperoleh siswa semester I atau genap di kelas VI SDN No. 42 Hulontalangi Kota Gorontalo.

Populasi pada penelitian ini adalah seluruh siswa di Sekolah Dasar Negeri No. 42 Hulonthalangi pada tahun ajaran 2020/2021 dengan jumlah siswa 105 orang. Dalam penelitian ini, sampel dipilih menggunakan teknik Sampling Purposive adalah teknik penentuan sampel dengan pertimbangan tertentu. dalam penelitian ini sampel adalah siswa kelas VI SDN No.42 Hulonthalangi.

Teknik pengumpulan data yaitu: kuisioner dan dokumentasi. Kuesioner atau angket digunakan untuk mengumpulkan gaya belajar. Dokumentasi dilakukan untuk mencari data-data yang sesuai seperti dokumen-dokumen hasil belajar siswa berupa:

1. Nilai PAS (Penilaian Akhir Semester) pada semester ganjil/I pada mata pelajaran IPA.

2. Daftar nama siswa yang akan dijadikan sebagai sampel penelitian.

Dalam penelitian ini akan menggunakan instrumen kuesioner atau angket. Angket ini digunakan untuk mengumpulkan data gaya belajar. Angket yang digunakan dalam penelitian ini adalah angket tertutup, yaitu angket yang sudah dilengkapi dengan jawaban sehingga siswa tinggal memilih jawaban saja. Angket dalam penelitian ini menggunakan model skala likert dengan 4 alternatif jawaban dan pemberian skor pada table 1. Berikut:

Tabel 1. Menggunakan Model Skala Likert Dengan 4 Alternatif Jawaban dan Pemberian

\begin{tabular}{|c|c|c|c|}
\hline \multicolumn{5}{|c|}{ Skor } \\
\hline Pertanyaan Positif & Skor & Pertanyaan Negatif & Skor \\
\hline Selalu (SLL) & 4 & Selalu (SLL) & 1 \\
\hline Sering (SRG) & 3 & Sering (SRG) & 2 \\
\hline Kadang-Kadang (KK) & 2 & Kadang-Kadang (KK) & 3 \\
\hline Tidak Pernah (TP) & 1 & Tidak Pernah (TP) & 4 \\
\hline
\end{tabular}

Adapun kisi-kisi angket penelitian yang digunakan pada tebel 2. sebagai berikut. 
Tabel 2. Kisi-Kisi Angket Penelitian

\begin{tabular}{|c|c|c|c|c|}
\hline \multirow[t]{2}{*}{ Variabel } & \multirow[t]{2}{*}{ Indikator } & \multicolumn{2}{|c|}{$\begin{array}{c}\text { No } \\
\text { Pertanyaan }\end{array}$} & \multirow[t]{2}{*}{$\begin{array}{c}\text { Jumlah } \\
\text { Pertayaan }\end{array}$} \\
\hline & & $\begin{array}{c}\text { Positif } \\
(+)\end{array}$ & $\begin{array}{l}\text { Negatif } \\
(-)\end{array}$ & \\
\hline \multirow{6}{*}{ Visual } & 1) Belajar dengan cara visual & $1,2,3$ & & 3 \\
\hline & 2) Rapi dan teratur & & 4 & 1 \\
\hline & 3) Berbicara dengan cepat & - & 5 & 1 \\
\hline & 4) Tidak terganggu oleh keributan & & 6 & 1 \\
\hline & 5) Pembaca cepat dan tekun & & 7 & 1 \\
\hline & $\begin{array}{l}\text { 6) Lebih suka membaca daripada } \\
\text { dibacakan }\end{array}$ & 8 & - & 1 \\
\hline \multirow{10}{*}{ Auditori } & $\begin{array}{l}\text { 7) Menjawab pertanyaan } \\
\text { singkat }\end{array}$ & 9 & - & 1 \\
\hline & 8) Lebih suka seni daripada musik & - & 10 & 1 \\
\hline & 1) Belajar dengan cara mendengar & & 11 & 1 \\
\hline & 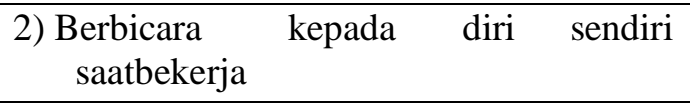 & 12 & - & 1 \\
\hline & 3) Mudah terganggu oleh keributan & & 13 & 1 \\
\hline & $\begin{array}{l}\text { 4) Menggerakkan bibir mereka dan } \\
\text { mengucapkan tulisan di buku ketika } \\
\text { membaca }\end{array}$ & 14 & - & 1 \\
\hline & $\begin{array}{l}\text { 5) Senang membaca dengan keras dan } \\
\text { mendengarkan }\end{array}$ & 15 & - & 1 \\
\hline & 6) Lebih suka musik daripada seni & 17 & 16 & 2 \\
\hline & $\begin{array}{l}\text { 7) Baik dalam aktivitas lisan ( suka } \\
\text { berbicara, suka berdiskusi, dan } \\
\text { menjelaskan sesuatu panjang lebar) }\end{array}$ & 18,19 & - & 2 \\
\hline & $\begin{array}{l}\text { 8) Lebih suka gurauan lisan daripada } \\
\text { membaca komik }\end{array}$ & - & 20 & 1 \\
\hline \multirow{6}{*}{ Kinestetik } & 1) Belajar dengan aktivitas fisik & 22 & 21 & 2 \\
\hline & 2) Lebih baik dalam aktivitas fisik & 23,25 & 24,26 & 4 \\
\hline & $\begin{array}{l}\text { 3) Menghafal dengan cara berjalan } \\
\text { dan melihat }\end{array}$ & 27 & & 1 \\
\hline & $\begin{array}{l}\text { 4) } \begin{array}{l}\text { Menggunakan jari } \\
\text { penunjuk ketika membaca }\end{array} \\
\text { magai }\end{array}$ & - & 28 & 1 \\
\hline & 5) Tulisannya sebagian besar jelek & 29 & - & 1 \\
\hline & $\begin{array}{lll}6) & \begin{array}{l}\text { Banyak menggunakam } \\
\text { tubuh }\end{array} & \text { isyarat } \\
\end{array}$ & 30 & - & 1 \\
\hline \multicolumn{2}{|r|}{ TOTAL } & 17 & 13 & 30 \\
\hline
\end{tabular}

Uji validitas instrumen dalam penelitian ini menggunakan penilaian ahli.Ahli diminta untuk memberikan pendapat tentang instrument yang telah disusun agar

AKSARA: Jurnal Ilmu Pendidikan Nonformal 
mengetahui apakah kuesioner tersebut telah mengungkap sesuatu yang hendak diukur dengan begitu butir-butir pertanyaan di dalam kusioner ini dapat dipertanggungjawabkan.

Teknik analisis data yang digunakan dalam penelitian ini adalah teknik analisis deskriptif dengan perhitungan presentase. Dilakukan skoring (penilaian) terhadap data variabel gaya belajar siswa dengan standar skor yang telah ditentukan. Kemudian disusun dalam tabel hasil angket gaya belajar. Selanjutnya masing-masing ata disajikan dalam tabel distribusi frekuensi skor dan tabel nilai frekuensi. Untuk menghitung sebaran presesntase dari frekuensi tersebut.

Dilakukan perhitungan skor pada angket gaya belajar dilanjutkan dengan penggolonggan kecenderungan gaya belajar siswa, masing-masing gaya belajar dihitung jumlah siswanya. Kemudian dibandingkan dengan jumlah seluruh siswa. Dilakukan pemberian tingkatan gaya belajar pada ketiga tipe gaya belajar yaitu visual, auditori, dan kinestetik. Disini peneliti menggolongkkan skor gaya belajar siswa menjadi 4 kategori, yaitu sangat baik, baik, cukup baik, dan kurang baik Widoyoko (dalam Damayanti 2016).

Berdasarkan penentuan kategori tabel di atas, maka disusun tabel 3. kategori pada gaya belajar siswa sebagai betikut:

\begin{tabular}{|c|c|}
\multicolumn{2}{c}{ Tabel 3. Kategori Gaya Belajar Siswa } \\
\hline Jumlah skor jawaban & Kategori \\
\hline $99-121$ & Sangat baik \\
\hline $76-98$ & Baik \\
\hline $53-75$ & Cukup baik \\
\hline $30-52$ & Kurang baik \\
\hline
\end{tabular}

\section{HASIL DAN PEMBAHASAN}

The results and discussion are presented in a section consisting of several paragraphs. This section is the most dominant part of the whole article, which is $60 \%$. To facilitate understanding and reading, the results of the research are described first, followed by the discussion section. Results and discussion subtitles are presented separately.

\section{Hasil}

Deskripsi Data Gaya Belajar Siswa

Data yang diperoleh dari angket gaya belajar dikategorikan sesuai dengan tipe gaya belajar menurut DePorter dan Hernacki (2005), yaitu visual, auditori, dan kinestetik. Masing-masing tipe gaya belajar memiliki jumlah butir yang sama, sehingga untuk mengkategorikannya dihitung dari jumlah pilihan jawaban terbanyak yang menunjukkan tipe gaya belajar. Angket gaya belajar pada penelitian ini terdiri dari 30 pertanyaan dengan alternatif pilihan jawaban berbentuk skala likert yang dibagikan kepada 22 siswa SDN No. 42 Hulonthalangi Kota Gorontalo. Skor yang digunakan untuk perhitungan angket pada setiap jawaban positif (+) adalah 4-1 dan negatif (-) 1-4 
dan akan menunjukkan tipe gaya belajar visual, auditorial dan kinestetik dengan melihat skor terbanyak pada ketiga tipe gaya belajar.

Berdasarkan jawaban siswa yang terdapat pada angket tersebut, terdapat siswa yang kecenderungan gaya belajar visual sebanyak 11 siswa, siswa dengan kecenderungan gaya belajar auditori sebanyak 7 siswa, dan siswa dengan kecenderungan gaya belajar kinestetik sebanyak 4 siswa. Selanjutnya dihitung presentase masing-masing gaya belajar sebagai berikut.

a Presentase gaya belajar visual

22

b. Presentase gaya belajar auditori

$$
-\quad={ }^{11} \square 100 \%=50 \%
$$

$$
\text { - }={ }^{7} \square 100 \%=31,81 \%=32 \%
$$

c. Presentase gaya belajar kinestetik $={ }^{4} \square 100 \%=18,18 \%=18 \%$ 22

Adapun dari presentase tersebut gaya belajar siswa disajikan dalam bentuk grafik sebagai berikut.

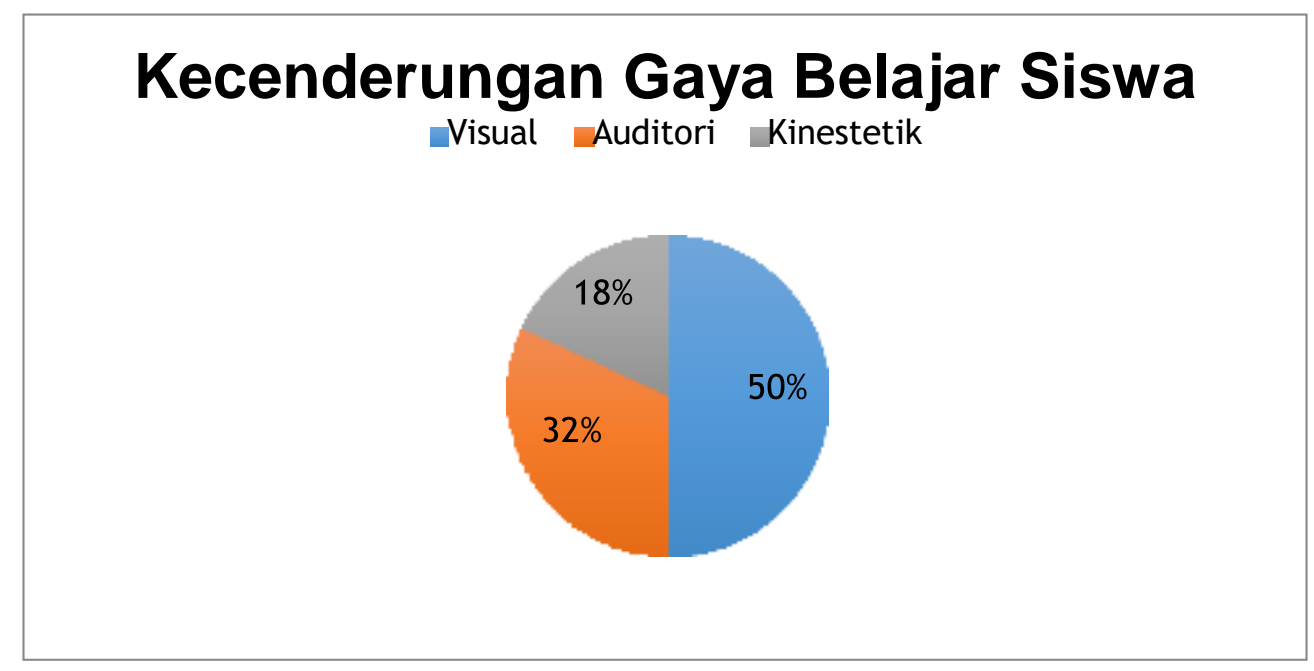

Gambar 1. Kecenderungan Gaya Belajar Siswa

Langkah selanjutnya peneliti membuat tabel kategori gaya belajar sesuai dengan pedoman yang tertulis pada teknik analisis data di atas. Kategori didasarkan pada jumlah skor jawaban seluruh siswa, diperoleh nilai maksimal $=4$ (skor butir maksimal) $\mathrm{x} 30$ (jumlah butir pertanyaan $)=120$. Nilai minimal $=1$ (skor butir minimal) $\times 30$ (jumlah butir pertanyaan $)=30$. Rentang $=120$ - 30 atau jumlah antara skor butir maksimal dan skor butir minimal yang telah dikalikan dengan jumlah butir pertanyaan yaitu 90 . Panjang kelas 90/4 = 22,5 dibulatkan 22 .

AKSARA: Jurnal Ilmu Pendidikan Nonformal 
Tabel 4. Presesntase Kategori Gaya Belajar Siswa

\begin{tabular}{|c|c|c|c|}
\hline Kategori & Skor & Jumlah Siswa & Presesntase (\%) \\
\hline Sangat baik & $99-121$ & 0 & $0 \%$ \\
\hline Baik & $76-98$ & 11 & $50 \%$ \\
\hline Cukup baik & $53-75$ & 11 & $50 \%$ \\
\hline Kurang baik & $30-52$ & 0 & $0 \%$ \\
\hline
\end{tabular}

Data skor variabel gaya belajar sisa akan disajikan ke dalam diagram sebagai berikut.

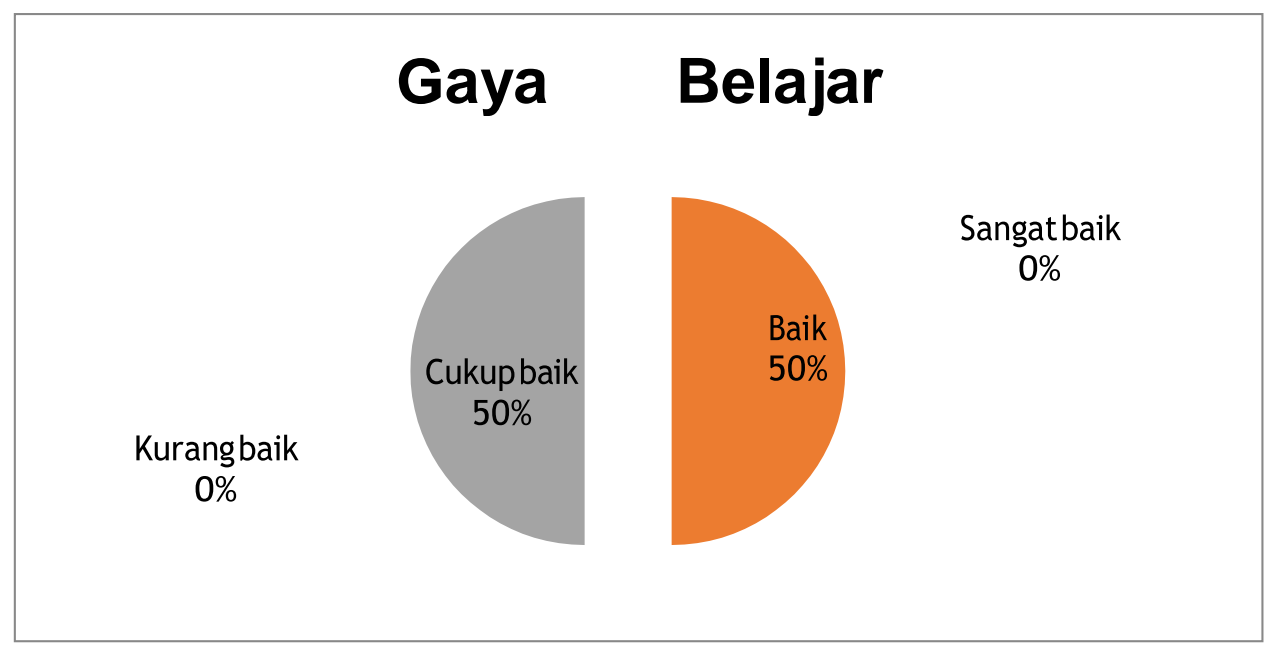

Gambar 2 Diagram Presentase Gaya Belajar Siswa

Pada diagram presesntase di atas bahwa gaya belajar siswa menunjukkan variabel gaya belajar siswa untuk kategori sangat baik tidak ada atau 0\%, kategori baik sebanyak 50\% (11 siswa), kategori cukup baik sebanyak 50\% (11 siswa), dan kategori kurang baik tidak ada atau $0 \%$. Berdasarkan hasil tersebut, dapat disimpulkan bahwa gaya belajar sebagaian siswa pada kelas VI SDN No. 42 Hulonthalangi Kota Gorontalo termasuk kategori baik dan cukup baik masing-masing yaitu sebesar $50 \%$. Gaya belajar pada siswa kelas VI SDN No. 42 Hulonthalangi Kota Gorontalo tidak terdapat pada kategori yang tinggi melainkan hanya pada baik dan cukup baik.

Untuk lebih mengetahui dan jelas mengenai gaya belajar siswa, berikut adalah uraian deskripsi pada masing-masing gaya belajar yaitu gaya belajar visual, gaya belajar auditori, dan gaya belajar kinestetik. 


\section{Gaya Belajar Visual}

Adapun yang akan disajikan di bawah ini untuk melihat presentase siswa pada gaya belajar visual sebagai berikut.

Tabel 5. Presesntase Kategori Gaya Belajar Visual

\begin{tabular}{|c|c|c|c|}
\hline Kategori & Skor & Jumlah Siswa & Presesntase (\%) \\
\hline Sangat baik & $33-40$ & 1 & $5 \%$ \\
\hline Baik & $25-32$ & 17 & $77 \%$ \\
\hline Cukup baik & $18-24$ & 4 & $18 \%$ \\
\hline Kurang baik & $10-17$ & 0 & $0 \%$ \\
\hline
\end{tabular}

Pada tabel 2. menunjukkan pada gaya belajar visual di kelas VI SDN No. 42 Hulonthalangi Kota Gorontalo terdapat $1(5 \%)$ siswa dengan gaya belajar visual sangat baik, 17 siswa dengan kategori baik pada gaya belajar visual atau $77 \%$ dan terdapat 4 siswa dengan kategori cukup baik pada gaya belajar visual $18 \%$.

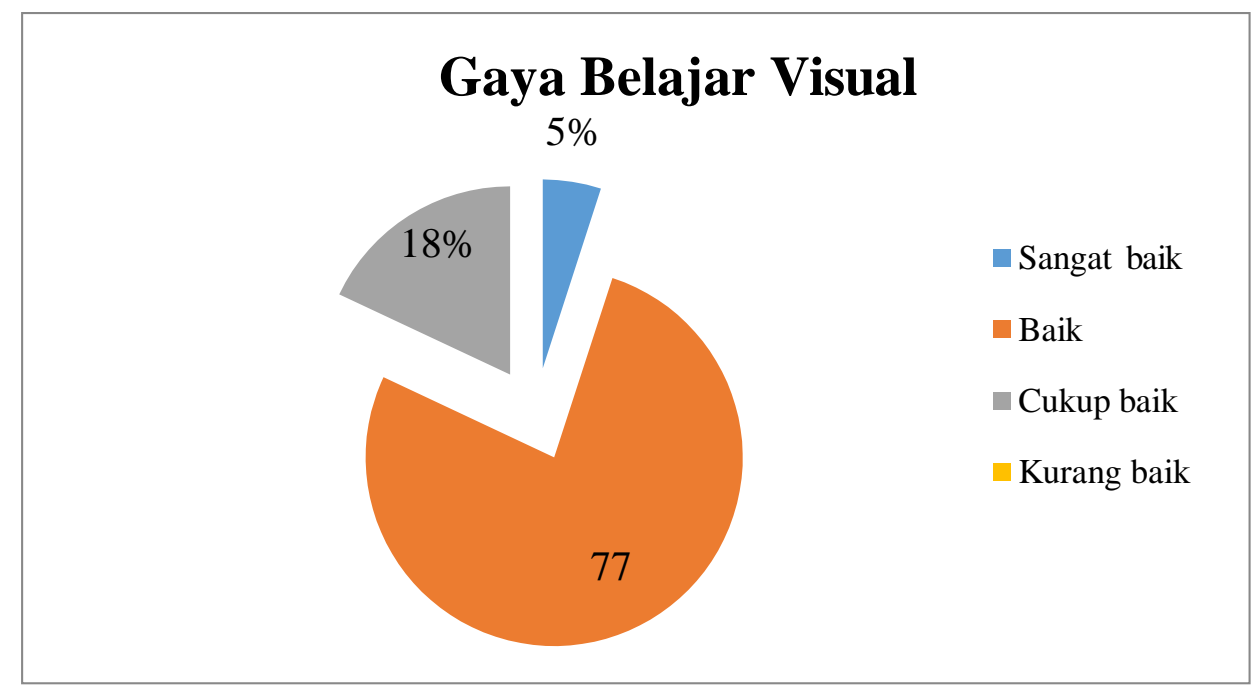

Gambar 3. Diagram Presesntase Gaya Belajar Visual

\section{Gaya Belajar Audiotori}

Adapun yang akan disajikan di bawah ini untuk melihat presentase siswa pada gaya belajar auditori sebagai berikut.

Tabel 6. Presesntase Kategori Gaya Belajar Auditori

AKSARA: Jurnal Ilmu Pendidikan Nonformal 


\begin{tabular}{|c|c|c|c|}
\hline Kategori & Skor & Jumlah Siswa & Presesntase (\%) \\
\hline Sangat baik & $33-40$ & 3 & $14 \%$ \\
\hline Baik & $25-32$ & 13 & $59 \%$ \\
\hline Cukup baik & $18-24$ & 6 & $27 \%$ \\
\hline Kurang baik & $10-17$ & 0 & $0 \%$ \\
\hline
\end{tabular}

Pada tabel 6. menunjukkan pada gaya belajar auditori di kelas VI SDN No. 42 Hulonthalangi Kota Gorontalo terdapat 3 (14\%) siswa dengan gaya belajar auditori pada kategori sangat baik, 13 siswa dengan kategori baik pada gaya belajar auditori atau 59\% dan terdapat 6 siswa dengan kategori cukup baik pada gaya belajar auditori $27 \%$.

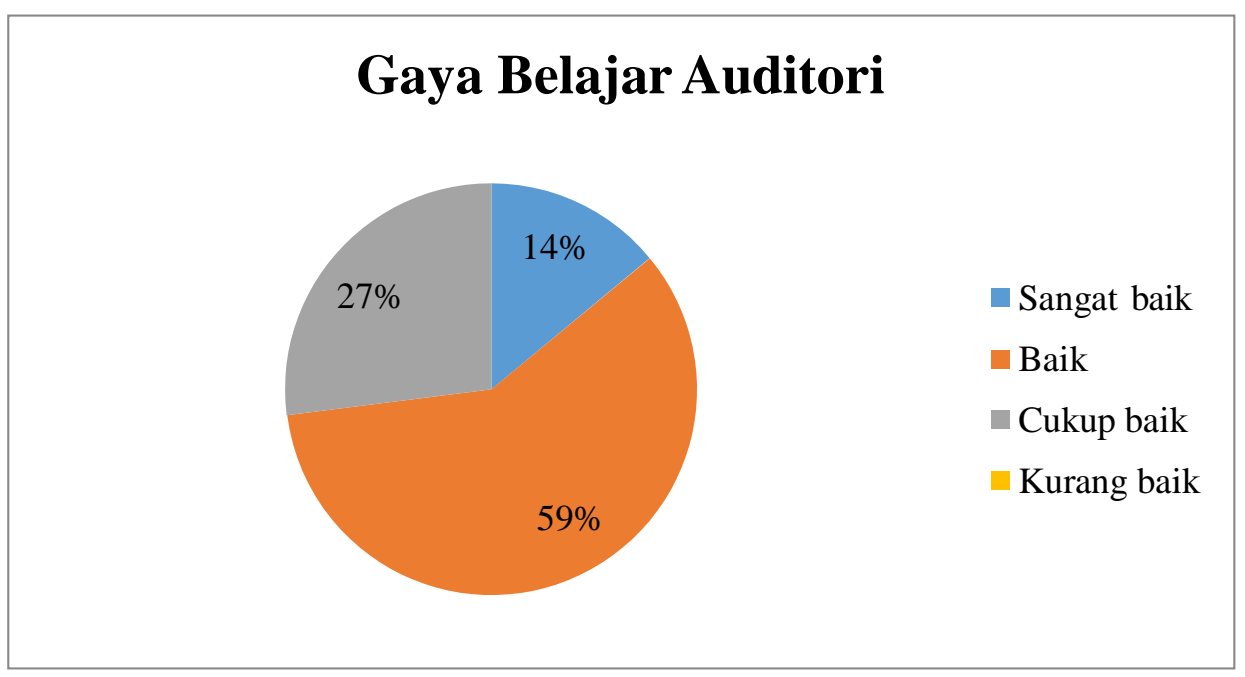

Gambar 4. Diagram Presesntase Gaya Belajar Auditori

\section{Gaya Belajar Kinestetik}

Adapun yang akan disajikan di bawah ini untuk melihat presentase siswa pada gaya belajar auditori sebagai berikut.

Tabel 7. Presesntase Kategori Gaya Belajar Kinestetik

\begin{tabular}{|c|c|c|c|}
\hline Kategori & Skor & Jumlah Siswa & Presesntase (\%) \\
\hline Sangat baik & $33-40$ & 0 & $0 \%$ \\
\hline Baik & $25-32$ & 9 & $41 \%$ \\
\hline Cukup baik & $18-24$ & 9 & $41 \%$ \\
\hline Kurang baik & $10-17$ & 4 & $18 \%$ \\
\hline
\end{tabular}


Pada tabel 7. menunjukkan pada gaya belajar kinestetik di kelas VI SDN No. 42 Hulonthalangi Kota Gorontalo tidak terdapat siswa dengan gaya belajar kinestetik pada kategori sangat baik, 9 siswa dengan kategori baik pada gaya belajar auditori atau $41 \%$, terdapat 9 siswa dengan kategori cukup baik pada gaya belajar auditori $41 \%$, dan terdapat 4 siswa dengan kategori kurang baik pada gaya belajar kinesetik atau $18 \%$.

Gambar 5. Diagram Presesntase Gaya Belajar Kinestetik

\section{Gaya Belajar Kinestetik}

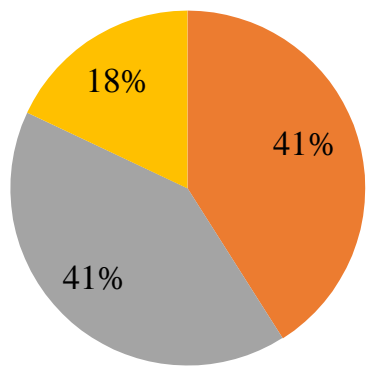

Sangat baik

Baik

Cukup baik

Kurang baik

\section{Hasil Belajar}

Data variabel hasil belajar ini merupakan data dokumentasi dari nilai PAS (Penilaian Akhir Semester) kelas VI pada semester I pada mata pelajaran IPA dari wali kelas VI di SDN No.42 Hulonthalangi Kota Gorontalo. Berdasarkan data nilai raport maka diperoleh nilai tertinggi, terendah, dan rata-rata di hitung menggunakan SPPS versi 25 dengan hasil sebagai berikut:

Tabel 8. Deskripsi Hasil Nilai PAS (Penilaian Akhir Semester) IPA Kelas VI SDN No.42 Hulonthalangi

\section{Descriptive Statistics}

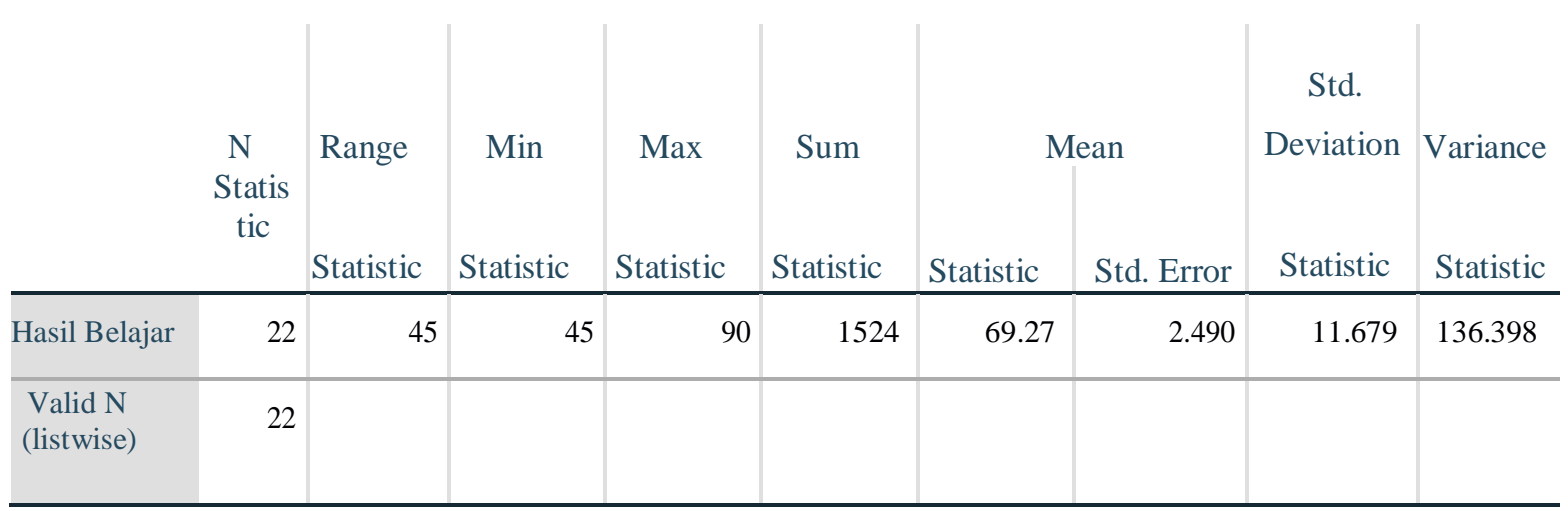


Pada tabel 8. merupakan tabel nilai PAS (Penilaian Akhir Semester) pada mata pelajaran IPA kelas VI yang berjumlah 22 siswa. Pada 22 siswa terdapat nilai tertinggi 90 dan nilai terendah 45. Adapun di bawah ini adalah hasil belajar melihat pada kecenderungan masing-masing tipe gaya belajar siswa di kelas VI pada mata pelajaran IPA dapat di lihat pada tabel berikut ini.

Tabel 9. Tabel Hasil Belajar Pada Tipe Gaya Belajar Visual

\begin{tabular}{|c|c|c|}
\hline NO & NAMA SISWA & HASIL BELAJAR \\
\hline 1 & AKS & 78 \\
\hline 2 & MRD & 58 \\
\hline 3 & MTN & 76 \\
\hline 4 & MAN & 68 \\
\hline 5 & MRP & 85 \\
\hline 6 & RAM & 77 \\
\hline 7 & AHS & 57 \\
\hline 8 & NAM & 74 \\
\hline 9 & NN & 72 \\
\hline 10 & NG & 74 \\
\hline 11 & DV & 78 \\
\hline
\end{tabular}

Pada tabel 9. ada 11 siswa yang memiliki kencederungan pada gaya belajar visual dengan berbagai nilai hasil belajar pada mata pelajaran IPA antara lain nilai dengan nilai 85 tertinggi dan 57 terendah pada siswa dengan kecenderungan gaya belajar visual. Nilai rata-rata pada siswa yang mempunyai gaya belajar visual yaitu 72,4.

Tabel 10. Tabel Hasil Belajar Pada Tipe Gaya Belajar Auditori

\begin{tabular}{|c|c|c|}
\hline NO & NAMA SISWA & HASIL BELAJAR \\
\hline 1 & HD & 90 \\
\hline 2 & HAF & 59 \\
\hline 3 & TAR & 75 \\
\hline 4 & ZU & 45 \\
\hline 5 & AW & 54 \\
\hline 6 & MAK & 78 \\
\hline 7 & NM & 68 \\
\hline
\end{tabular}

Pada tabel 10 ada 7 siswa yang memiliki kencederungan pada gaya belajar auditori dengan berbagai nilai hasil belajar pada mata pelajaran IPA yaitu dengan nilai antara 90 nilai tertinggi dan 45 nilai terendah pada kecenderungan gaya belajar auditori. Nilai ratarata pada siswa yang mempunyai gaya belajar auditori yaitu 67 . 
Tabel 11. Tabel Hasil Belajar Pada Tipe Gaya Belajar Kinestetik

\begin{tabular}{|c|c|c|}
\hline NO & NAMA SISWA & HASIL BELAJAR \\
\hline 1 & MRN & 73 \\
\hline 2 & SSB & 47 \\
\hline 3 & JAT & 64 \\
\hline 4 & SSM & 74 \\
\hline
\end{tabular}

Pada tabel 11. ada 4 siswa yang memiliki kecenderungan pada gaya belajar kinestetik dengan nilai yang berbeda pada hasil belajar pada mata pelajaran IPA yaitu antara nilai 74 yang tertinggi dan 47 yang terendah. Nilai rata-rata pada siswa yang mempunyai gaya belajar kinestetik yaitu 64,5.

\section{Pembahasan}

Pemberian angket ditemukan gaya belajar pada 22 responden terdapat pada penggolangan kecenderungan siswa bahwa terdapat 11 siswa dengan gaya belajar visual, 7 siswa dengan gaya belajar auditori, dan 4 siswa dengan gaya belajar kinestetik. Pada presesntase untuk kategori gaya belajar siswa dari 22 siswa kelas VI SDN No. 42 Hulonthalangi Kota Gorontalo memeliki gaya belajar pada kategori baik (50\%) dan cukup baik $(50 \%)$. Untuk masing-masing kategori gaya belajar visual, auditori, dan kinestetik memiliki presestase yang beragam. Pada variabel gaya belajar siswa untuk kategori baik rata-rata hasil belajar mereka pada mata pelajaran IPA yaitu 54-90. Untuk kategori cukup baik pada variabel gaya belajar siswa mempunyai hasil belajar pada mata pelajaran IPA yaitu 45-85.

Presentase kategori gaya belajar visual pada siswa kelas VI SDN No. 42 Hulonthalangi yaitu terdapat 1 siswa dengan kategori gaya belajar visual sangat baik, untuk kategori baik terdapat 17 siswa, dan 4 siswa terdapat pada kategori cukup baik untuk gaya belajar visual. 1 siswa yang memiliki kategori sangat baik pada gaya belajar visual mempunyai hasil belajar pada mata pelajaran IPA yaitu 78. 17 siswa yang memiliki gaya belajar visual dengan kategori baik mempunyai hasil belajar pada mata pelajaran IPA beragam yaitu 54-90. Pada 4 siswa yang memiliki kategori gaya belajar visual cukup baik mempunyai hasil belajar pada mata pelajaran IPA yaitu 47-73.

Presentase kategori gaya belajar auditori pada siswa kelas VI SDN No. 42 Hulonthalangi yaitu terdapat 3 siswa dengan kategori gaya belajar auditori sangat baik, untuk kategori baik terdapat 13 siswa, dan 6 siswa terdapat pada kategori cukup baik untuk gaya belajar auditori. 3 siswa yang memiliki kategori sangat baik pada gaya belajar auditori mempunyai hasil belajar pada mata pelajaran IPA yaitu 68-78. 13 siswa yang memiliki gaya belajar auditori dengan kategori baik mempunyai hasil belajar pada mata pelajaran IPA beragam yaitu 45-90. Pada 6 siswa yang memiliki kategori gaya belajar auditori cukup baik mempunyai hasil belajar pada mata pelajaran IPA yaitu 47-85. 
Presentase kategori gaya belajar kinestetik pada siswa kelas VI SDN No. 42 Hulonthalangi yaitu terdapat 9 siswa dengan kategori gaya belajar kinestetik baik, untuk kategori cukup baik terdapat 9 siswa, dan 4 siswa terdapat pada kategori kurang baik untuk gaya belajar kinestetik. 9 siswa yang memiliki kategori baik pada gaya belajar kinestetik mempunyai hasil belajar pada mata pelajaran IPA yaitu 57-90. 9 siswa yang memiliki gaya belajar kinestetik dengan kategori cukup baik mempunyai hasil belajar pada mata pelajaran IPA beragam yaitu 45-77. Pada 4 siswa yang memiliki kategori gaya belajar kinestetik kurang baik mempunyai hasil belajar pada mata pelajaran IPA yaitu 68-85.

Pada kecenderungan gaya belajar siswa masing-masing pada gaya belajar visual, auditori dan kinestetik mempunyai hasil belajar yang beragam dan tidak jauh berbeda. Pada kecenderungan gaya belajar visual terdapat 11 siswa dengan hasil belajar 85 tertinggi dan 57 terendah dengan nilai rata-ratanya yaitu 72,4. Pada kecenderungan gaya belajar auditori terdapat 7 siswa dengan hasil belajar 90 nilai tertinggi dan 45 nilai terendah dengan nilai rata-ratanya yaitu 67. Kecenderungan gaya belajar kinestetik terdapat 4 siswa yang mempunyai hasil belajar 74 nilai yang tertinggi dan 47 nilai yang terendah dengan nilai rata-ratanya yaitu 64,5 .

Gaya belajar visual lah yang terbanyak pada kelas VI SDN No.42 Hulonthalangi dan kemudian auditori dan kinestetik. Hal tersebut terjadi karena kecenderungan pada gaya belajar siswa dapat berubah karena sudah terbiasa dimaksimalkan pada kecenderungan gaya mengajar guru tersebut. Persitiwa itu terjadi pada kelas VI SDN No.42 Hulonthalangi. Berdasarkan pengamatan peneliti selama beberapa kali mengikuti pembelajaran saat Praktek Pengalaman Lapangan (PPL), guru kelas VI cenderung mengajar dengan gaya visual dan auditori. Contohnya pada gaya belajar visual dan auditori terdapat siswa yang mempunyai gaya belajar tersebut dengan sangat baik. Guru sering menjelaskan materi pelajaran sembari siswa diminta memperhatikannya pada buku teks yang ada pada masing-masing siswa serta jarangannya guru melakukan simulasi atau eksperimen pada saat pembelajaran membuat sedikit siswa dengan gaya belajar kinestetik. Bisa dilihat juga pada presesntase kategori gaya belajar kinestetik lah terdapat kategori kurang baik dan tidak mempunyai kategori yang sangat baik.

Siswa telah terbiasa dengan gaya mengajar guru dan kencenderungan itu terbentuk pada gaya mengajar guru yang dapat dilihat dari gaya belajar siswa masih sangat berubahubah dan menyesuaikan dengan gaya guru dalam mengajar. Jadi dalam penelitian ini, hal yang terpenting yaitu siswa dapat mengetahui gaya belajar yang mereka miliki. Sehingga siswa dapat belajar dengan menggunakan gaya belajar mereka dan merasa nyaman saat belajar dan bagi guru diharapkan dapat mengetahui masing-masing gaya belajar siswa sehingga bisa mengoptimalkan dan menyesuaikan cara mengajarnya dengan gaya belajar siswa. Sehingga gurupun dapat mengajar dengan berbagai gaya belajar yang ada pada siswa untuk meningkatkan hasil belajar siswa terutama pada mata pelajaran IPA karena masih ada nilai yang dibawah KKM dan menjadikan pembelajaran yang lebih variatif dan efektif. 


\section{SIMPULAN}

Berdasarkan hasil penelitian ini, maka dapat diambil kesimpulan bahwa :

1. Data yang diperoleh dari angket gaya belajar dikategorikan sesuai dengan tipe gaya belajar yaitu visual, auditori, dan kinestetik. Masing- masing tipe gaya belajar memiliki jumlah butir yang sama, sehingga untuk mengkategorikannya dihitung dari jumlah pilihan jawaban terbanyak yang menunjukkan tipe gaya belajar. Angket gaya belajar pada penelitian ini terdiri dari 30 pertanyaan dengan alternatif pilihan jawaban berbentuk skala likert yang dibagikan kepada 22 siswa SDN No. 42 Hulonthalangi Kota Gorontalo. Diperoleh gaya belajar siswa dengan masing-masing gaya belajar visual 11 siswa, auditori 7 siswa dan kinestetik 4 siswa.

2. Perbedaan hasil belajar siswa kelas VI ditinjau dari gaya belajar pada mata pelajaran IPA SDN No.42 Hulonthlangi Kota Gorontalo terlihat pada nilai rata-rata. Siswa yang memiliki kecenderungan gaya belajar visual mempunyai nilai rata-rata 72,4, siswa yang memiliki kecenderungan gaya belajar auditori mempunyai nilai rata-rata 67 , dan siswa yang memiliki kecenderungan gaya belajar kinestetik mempunyai nilai rata-rata yaitu 64,5

\section{REFERENCES}

Agustina, Riza. 2017. Hubungan Gaya Belajar Siswa Dengan Hasil Belajar Siswa Kelas IV Pada Mata Pelajaran IPA di Madrasyah Ibtidaiyah Mahad Islami Palembang. Skripsi. Palembang: Program Studi Pendidikan Guru Madrasyah Ibtidaiyah Fakultas Ilmu Tarbiyah dan Keguruan Universitas Islam Ngeri Raden Fatah.

Anggitasari, Binta. 2018. Hasil belajar matematika ditinjau dari motivasi dan gaya belajar siswa. Program Studi Pendidikan Matematika Fakultas Keguruan dan Ilmu Pendidikan Universitas Muhammadiyah Surakarta.

Arikunto, Suharsimi. 2014. Prosedur Penelitian: Suatu Pendekatan Praktik. Jakarta: Rineka Cipta.

Damayanti, Lina. 2016. Hubungan Gaya Belajar Siswa Dengan Hasil Belajar IPS Pada Siswa Kelas V SDN Di Gugus Wibisono Kecamatan Jati Kabupatn Kudus. Skripsi. Semarang: Pendidikan Guru Sekolah Dasar Fakultas Ilmu Pendidikan Universitas Negeri Semarang.

Deporter B, Mark R dan Sarah S N. 2007. Quantum Teaching: Mempraktikkan Quantum Learning di Ruang-ruang Kelas. Penerjemah: Ary Nilandari. Bandung: Kaifa.

Deporter, Bobbi \& Mike H. 2005. Quantum Learning: Membiasakan Belajar Nyaman dan Menyenangkan. Penerjemah: Alwiyah Abdurrahman. Bandung: Kaifa.

Fitriani, Cris H (2017). Gaya belajar siswa kelas iii b sdn tukangan yogyakarta.Jurnal Pendidikan Guru Sekolah Dasar. Diakses pada tanggal 03 Juli 2019.

Hujaemah, emah dkk (2019). Pengaruh Penerapan Model Snowball Throwing Terhadap Hasil Belajar Ipa Di Sekolah Dasar. Jurnal Madrasah Ibtidaiyah, Vol. 5 No. 1. Diakses pada tanggal 11 September 2020.

Iskandar, dkk (2018). Pendekatan Science Technology Society: Ipa Di Sekolah Dasar. Jurnal Ilmiah Pendidikan Guru Sekolah Dasar, Vol. 2 No. 2. Diakses pada tanggal 11 September 2020.

AKSARA: Jurnal Ilmu Pendidikan Nonformal 
Khumairah, Laila. 2017. Hubungan Motivasi Belajar Dengan Hasil Belajar IPS. Skripsi. Bandar Lampung: Fakultas Keguruan Ilmu Pendidikan Universitas Lampung.

Kusumawati, dkk (2018). Gaya Belajar Siswa Berprestasi Pada Mata Pelajaran Matematika Kelas V SD Negeri 03 Cibelok Pemalang.Jurnal Pesona Dasar, Vol 6, No.2. Diakses pada tanggal 03 Juli 2019.

Maisoroh dan Rostrieningsih. (2010). Peningkatan Hasil Belajar Siswa Dengan Menggunakan Metode Pembelajaran Active Learning Tipe Quiz Team Pada Mata Pelajaran Keterampilan Dasar Komunikasi Di Smk Negeri 1. Jurnal Pendidikan dan Ekonomi, Vol 8, No 2. Diakses pada tanggal 06 September 2020.

Mulyani, Sri (2017). Penggunaan Media Kartu (Flash Card) dalam Meningkatkan Hasil Belajar Konsep Mutasi bagi Peserta Didik Kelas XII. Jurnal Profesi Keguruan. Diakses 06 September 2020.

Murfiah, Uum. (2017). Pembelajaran Terpadu: Teori \& Praktik Terbaik di Sekolah. Bandung: PT Refika Aditama.

Pertiwi (2015). Perbedaan Tingkat Prestasi Belajar Ditinjau Dari Kecenderungan Gaya Belajar Siswa Sekolah Dasar. Skripsi. Yogyakarta: Fakultas Ilmu Pendidikan Universitas Negeri Yogyakarta.

Rahman A Aisyah dan Susi Yanti (2016). Pengaruh Gaya Belajar Terhadap Hasil Belajar Siswa Pada Mata Pelajaran IPS Terpadu Di Kelas VII SMP Negeri 1 Peudada. Jurnal Pendidikan Almuslim Vol IV, No 2. Diakses 06 September 2020.

Sari, Erlina (2019). Siswa Pada Mata Pelajaran Ekonomi Di Kelas XI IPS SMA Negeri 5 Padangsidimpuan. Jurnal Education and Development, Vol 7, No (2). Diakses pada tanggal 06 November 2019.

Sudjana. 2005. Metode Statistika. Bandung, Tarsito

Sugiyono. 2017. Metode Penelitian Pendidikan. Bandung: Alfabeta. Sugiyono. 2017. Statistika Untuk Penelitian. Bandung: Alfabeta.

Suyono, Akhmad (2018). Pengaruh Gaya Belajar Terhadap Hasil Belajar Pada Mata Pelajaran Akuntansi Kelas XI IPS SMA N 3 Tapung. Jurnal Pendidikan Ekonomi Akuntansi, Vol 6, No 1. Diakses pada tanggal 06 September 2020. 
AKSARA: Jurnal Ilmu Pendidikan Nonformal

P-ISSN 2407-8018 E-ISSN 2721-7310 DOI prefix $\underline{10.37905}$

Volume 08, (1), January 2022

http://ejurnal.pps.ung.ac.id/index.php/Aksara

562 AKSARA: Jurnal Ilmu Pendidikan Nonformal 